\title{
Rinoplasti Hastalarının Kişisel Değişkenlere Bağlı Memnuniyetlerinin Değerlendirilmesi
}

\author{
Başak ÇAYPINAR ESER* ${ }^{*}$ A. Emre ILLHAN**
}

\section{$\ddot{O} \mathbf{z}$}

Amaç: Dünya genelinde yapılan araştırmalarda burun cerrahilerinin yalnızca \% 10’u sadece fonksiyona bağlıyken, geri kalanının görsel değişikliği amaçladığı bildirilmiştir. Kozmetik rinoplasti için giderek artan istek dünyanın belli kısımlarında ileri bilimsel değerlendirme gerektirmektedir. Düşük özbeğeni, olumsuz vücut imajı ile ilgili anksiyete ve bazı psikolojik kişisel özellikler (mükemmelliyetçilik veya obsessif-kompulsif, bipolar ve psikozun diğer özellikleri) estetik cerrahi için motivasyon oluşturabilir. Mevcut çalışmamız, rinoplasti hastalarımızda demografik değişkenleri (yaş, cinsiyet, evlilik, eğitim seviyesi, çocuk sahibi olma) ve psikolojik değişkenleri (daha önce psikiyatrik tedavi almış olma veya psikiyatrik tedavisinin devam etme durumu) değerlendirmektedir.

Yöntem: Çalışmamızda 99 hasta değerlendirilmiştir ve hastalarımızın hepsi kliniğimize estetik amaçlı rinoplasti için başvuran hastalardır. Bu çalışma değişkenleri demografik değişkenleri (yaş, cinsiyet, evlilik, eğitim seviyesi, çocuk sahibi olma) ve psikolojik değişkenleri (daha önce psikiyatrik tedavi almış olma veya psikiyatrik tedavisinin devam etme durumu) içermektedir.

'Rosenberg Benlik Saygısı Ölçĕgi' (RBSÖ) ve 'Sosyal Görünüş Kaygı Ölçeği' (SGKÖ) ile skorlama sonrası değişkenlerle olan anlamlılık sorgulanmıştır.

\footnotetext{
Özgün Araştırma Makalesi (Original Research Article)

Geliş / Received: 08.08.2021 \& Kabul / Accepted: 11.08.2021

DOI: https://doi.org/10.38079/igusabder.980429

* Dr. Öğr. Üyesi, İstanbul Gelişim Üniversitesi, Sağlık Bilimleri Fakültesi, Odyoloji Bölümü, İstanbul, Türkiye, E-posta: bskcypnr@hotmail.com ORCID https://orcid.org/oooo-0002$3782-4738$

${ }_{* *}^{*}$ Dr., Rinocenter Özel Klinik, İstanbul, Türkiye, E-posta: emreilhanyayin@gmail.com ORCID https://orcid.org/o0o0-0001-5.513-1161
}

ETÍK BÍLDİRIM: Çalışma, İstanbul Gelişim Üniversitesi Etik Kurulu tarafindan 15.04.2021 tarih ve 2021-13-23 karar numarası ile onaylanmıştır. 
Bulgular: Olguların ameliyat öncesine göre ameliyat sonrası RBSÖ puanlarında gözlenen artış istatistiksel değerlendirmede anlamlı kabul edilmiştir ( $\mathrm{p}<0.001)$. Bu da ameliyatın RBSÖ ölçeğine dayanarak olumluluk göstergesi olarak kabul edilebilir.

Olguların ameliyat öncesine göre ameliyat sonrası SGKÖ puanlarında gözlenen düşüş istatistiksel verilerde anlamlılık arz etmiştir ( $\mathrm{p}<0.001$ ). Bu da ameliyatın SGKÖ ölçeğine dayanarak olumluluk göstergesi olarak kabul edilebilir.

Sonuç: Çalışmamızda bazı parametrelerin, genel geçer kabul gören bazı hipotezleri destekler tarzda olduğu görülürken, bazı parametlerin ise sanılanın aksine benlik saygısı veya sosyal görünüş kaygısı üzerinde etkili olmadığını saptadık.

Anahtar Kelimeler: Rinoplasti, psikoloji, psikiyatri, benlik kaygısı, sosyal görünüş

\title{
Evaluation of Rhinoplasty Patients for Satisfaction on Rhinoplasty Results in the Name of Personal Variations
}

\begin{abstract}
Aim: In studies conducted around the world, it has been reported that only $10 \%$ of nose surgeries are only dependent on function, while the rest aim for the cosmetic goals of patients.The growing desire for cosmetic rhinoplasty requires further scientific evaluation in certain parts of the world. Low self-esteem, anxiety about negative body image, and some self-psychological personalities (perfectionism or obsessive-compulsive disorders, bipolar disorder, and some kinds of psychosis) may create motivation for cosmetic surgery. Our current study evaluates our rhinoplasty patients in the name of demographic variables like age, gender, education level, parenting and psychiatric characteristics like having medication before and continuing.

Method: We included 99 patients in our detection who applied to our clinic for cosmetic desire. Our study contains demographic variables like age, gender, education level, parenting and psychiatric characteristics like having medication before and continuing. All variables are evaluated with Rosenberg Self-Esteem Scale (RSES) and Social Appearance Anxiety Scale-scoring system (SAAS) statistically.

Results: The increase of the postoperative values in the RSES scoring analyses compared to preoperative results can be evaluated as significant statistically $(\mathrm{p}<0.001)$. Similarly the decreasing of values in the SAAS scoring analyses with operation is statistically significant $(\mathrm{p}<0.001)$.
\end{abstract}

Conclusion: We found that some of the parameters support very known hypotheses in literature, but on the contrary, some are having no effect on Rosenberg Self-Esteem Scale (RSES) and Social Appearance Anxiety Scale (SAAS). 
Keywords: Rhinoplasty, psychiatry, self-esteem scale, social appearance

\section{Giriş}

Dünya genelinde yapılan araştırmalarda burun cerrahilerinin yalnızca \% $10 \mathrm{u}$ sadece fonksiyona bağlıyken, geri kalanının görsel değişikliği amaçladığı bildirilmiştir ${ }^{1}$.

Düşük özbeğeni, olumsuz vücut imajı ile ilgili anksiyete ve bazı psikolojik kişisel özellikler (mükemmelliyetçilik veya obsessif-kompulsif, bipolar ve psikozun diğer özellikleri) estetik cerrahi için motivasyon oluşturabilir²-4. Bazı önceki çalışmalar estetik cerrahi isteyen hastalarda anlamlı psikopatoloji raporlamıştır'1,5.

Gözlemlenen en ciddi psikopatolojiler obsessif-kompulsif bozukluklar, depresyon, kişilik problemleri, psikotik bozukluk, paranoya, düşmanlık, fobi, ve genel psikopatolojidir ${ }^{6}$.

Diğerleri hastaların \% 70 inde tanı konmuş psikiyatrik bozukluk, depresyon ve nöroz ve pasif-agresif kişilik bulmuştur7.

Green ve arkadaşları vücut imajı ile ilgili tatminsizlik ve anksiyete ile mental rahatsızlıkların hastaları estetik cerrahiye zorladığını belirtmişlerdir8 ${ }^{8}$ Bazı bilim adamları estetik cerrahi yaptıran çoğu kişinin özbeğenisinin fiziksel görüntü bağıntılı olduğunu ve bu yüzden cerrahi değişim aradıklarını ifade etmişlerdir ${ }^{9}$. Diğer araştırmacılar ise bu kişilerin psikolojik olarak tamamen sağlıklı olduklarını ve sadece görüntülerinin daha iyi olmasını amaçladıklarını belirtmişlerdir ${ }^{10-12}$.

Görsel değişikliği amaçlayan estetik cerrahilerde, psikolojik etmenler hem prognozda ve postoperatif dönemdeki memnuniyette önemli bir rol oynamaktadır ${ }^{13}$.

Başka bir çalışmada estetik amaçlı rinoplasti yapılanların gönüllü psikolojik değerlendirilmesinde, özbeğeninin ve vücut imajının postoperatif komplikasyonları önlediği önerilmiştir44.

Psikologlara göre bir toplumdaki başarısız estetik cerrahi algısı katılımcıların algısal ve duygusal motivasyonlarından çok etkilenmektedir. Cerrahi isteyen hastalarda psikolojik karakteristikleri, mükemmelliyetçiliği ve vücut imajını inceleyen pek çok çalışma yapılmıştır ${ }^{14,15}$. 
Çalışmalarda estetik cerrahi için başvuran hastaların psikolojik karakteristikleri ile rinoplasti isteği ve tatmini arasında anlamlı korelasyon bulunmuştur7,16. Kozmetik rinoplasti için giderek artan istek dünyanın belli kısımlarında ileri bilimsel değerlendirme gerektirmektedir. Mevcut çalışmamız, rinoplasti hastalarımızda demografik değişkenleri (yaş, cinsiyet, evlilik, eğitim seviyesi, çocuk sahibi olma) ve psikolojik değişkenleri (daha önce psikiyatrik tedavi almış olma veya psikiyatrik tedavisinin devam etme durumu) değerlendirmektedir.

\section{Gereç ve Yöntem}

Çalışma İstanbul Gelişim Üniversitesi tarafından 15.04.2021 tarih ve 2021-13-23 karar numarası ile onaylanmıştır. Çalışmamızda 99 hasta değerlendirilmiştir ve hastalarımızın hepsi kliniğimize estetik amaçlı rinoplasti için başvuran hastalardır.

Bu çalışmanın değişkenleri demografik değişkenleri (yaş, cinsiyet, evlilik, eğitim seviyesi, çocuk sahibi olma) ve psikolojik değişkenleri (daha önce psikiyatrik tedavi almış olma veya psikiyatrik tedavisinin devam etme durumu) içermektedir.

'Rosenberg Benlik Saygısı Ölçeği’ (RBSÖ) ile ve ‘Sosyal Görünüş Kaygı Ölçeği’ (SGKÖ) ile puanlama yapılıp değişkenlerle olan anlamlılık değerlendirilmiştir.

Bireylerin benlik saygısı değerlendirmesi için kullanılan Rosenberg Benlik Saygısı Ölçeği, toplamda 10 yargıdan oluşmaktadır. Hastalar her bir yargıya çok doğru veya doğru, yanlış veya çok yanlış ifadelerinden birini seçmektedir. Biz de bunlara göre 1,2,3,4 olarak puanlayıp istatistik olarak değerlendirdik. Aynı şekilde Sosyal Görünüş Kaygı Ölçeği 16 yargıdan oluşur ve hastalar her bir tespit hiç uygun değil veya uygun değil, biraz uygun veya uygun veyahut tamamen uygun şeklinde yanıtlamışlardır. Yanıtlar 1-5 arasında puanlanmıştır ve istatiksel olarak değerlendirilmiştir (Şekil 1, Ș̣ekil 2). 
Şekil 1. Rosenberg Benlik Saygısı Ölçeği

\begin{tabular}{|c|c|c|c|c|c|}
\hline D-1 & ROSENBERG BENLİK SAYGISI ÖLÇEĞİ & $\begin{array}{l}\text { ÇOK } \\
\text { DOĞRU }\end{array}$ & DOĞRU & YANLIȘ & $\begin{array}{c}\text { ÇOK } \\
\text { YANLIS }\end{array}$ \\
\hline \multirow{3}{*}{ Madde 1} & 1. Kendimi en az diğer insanlar kadar değerli buluyorum & & & & \\
\hline & 2. Bazı olumlu özelliklerim olduğunu düşünüyorum. & & & & \\
\hline & 3. Genelde kendimi başarısız bir kişi olarak görme eğilimindeyim & & & & \\
\hline \multirow{2}{*}{ Madde 2} & $\begin{array}{l}\text { 4. Ben de diğer insanların birçoğunun yapabildiği kadar bir şeyler } \\
\text { yapabilirim. }\end{array}$ & & & & \\
\hline & 5. Kendimde gurur duyacak fazla bir şey bulamıyorum. & & & & \\
\hline Madde 3 & 6. Kendime karşı olumlu bir tutum içindeyim. & & & & \\
\hline Madde 4 & 7. Genel olarak kendimden memnunum. & & & & \\
\hline Madde 5 & 8. Kendime karşı daha fazla saygı duyabilmeyi isterdim. & & & & \\
\hline \multirow{2}{*}{ Madde 6} & 9. Bazen kendimin bir işe yaramadığını düşünüyorum. & & & & \\
\hline & 10. Bazen kendimin hiç de yeterli bir insan olmadığımı düşünüyorum & & & & \\
\hline
\end{tabular}

\section{Şekil 2. Sosyal Görünüş Kaygısı Ölçeği}

\begin{tabular}{|c|c|c|c|c|c|}
\hline SOSYAL GÖRÜNÜŞ KAYGISI ÖLÇEĞİ & $\begin{array}{l}\text { Hiç } \\
\text { Uygun } \\
\text { Değil }\end{array}$ & $\begin{array}{l}\text { Uygun } \\
\text { Değil }\end{array}$ & $\begin{array}{l}\text { Biraz } \\
\text { Uygun }\end{array}$ & Uygun & $\begin{array}{l}\text { Tamamen } \\
\text { Uygun }\end{array}$ \\
\hline 1. Dış görünüşümle ilgili kendimi rahat hissederim & & & & & \\
\hline 2. Fotoğrafim çekilirken kendimi gergin hissederim. & & & & & \\
\hline 3. İnsanlar doğrudan bana baktıklarında gerilirim. & & & & & \\
\hline $\begin{array}{l}\text { 4. Insanların görünüşümden dolayı benden hoşlanmayacakları konusunda } \\
\text { endişelenirim. }\end{array}$ & & & & & \\
\hline $\begin{array}{l}\text { 5. Yanlarında olmadığım zamanlarda insanların görünüşümle ilgili } \\
\text { kusurlarımı konuşacaklarından endişelenirim. }\end{array}$ & & & & & \\
\hline $\begin{array}{l}\text { 6. Görünüșümden dolayı insanların benimle beraber vakit geçirmek } \\
\text { istemeyeceklerinden endişelenirim. }\end{array}$ & & & & & \\
\hline 7. İnsanların beni çekici bulmamalarından korkarım. & & & & & \\
\hline 8. Görünüşümün yaşamımı zorlaştıracağından endişe duyarım & & & & & \\
\hline $\begin{array}{l}\text { 9. Karşıma çıkan firsatları görünüşümden dolayı kaybetmekten } \\
\text { kaygılanırım. }\end{array}$ & & & & & \\
\hline 10. İnsanlarla konuşurken görünüşümden dolayı gerginlik yaşarım. & & & & & \\
\hline 11. Diğer insanlar görünüşümle ilgili bir şey söylediklerinde kaygılanırım. & & & & & \\
\hline $\begin{array}{l}\text { 12. Dış görünüşümle ilgili başkalarının beklentilerini karşılayamamaktan } \\
\text { endişeleniyorum }\end{array}$ & & & & & \\
\hline $\begin{array}{l}\text { 13. İnsanların görünüşümü olumsuz olarak değerlendirecekleri konusunda } \\
\text { endişelenirim. }\end{array}$ & & & & & \\
\hline $\begin{array}{l}\text { 14. Diğer insanların görünüșümdeki bir kusurun farkına vardıklarını } \\
\text { düşündüğümde kendimi rahatsız hissederim. }\end{array}$ & & & & & \\
\hline $\begin{array}{l}\text { 15. Sevdiğim kişinin görünüşümden dolayı beni terk edeceğinden endişe } \\
\text { duyuyorum }\end{array}$ & & & & & \\
\hline $\begin{array}{l}\text { 16. İnsanların görünüşümün iyi olmadığını düşünmelerinden } \\
\text { endişeleniyorum. }\end{array}$ & & & & & \\
\hline
\end{tabular}




\section{İstatistiksel Analiz}

İstatistiksel değerlendirmeler açısından NCSS (Number Cruncher Statistical System) 2007 (Kaysville, Utah, USA) sistemi uygulandı. Çalışma bulguları analiz edilirken tanımlayıcı istatistiksel değerlendirmelerin (ortalama, standart sapma, medyan, birinci çeyreklik $\left(Q_{1}\right)$, üçüncü çeyreklik $\left(Q_{3}\right)$, frekans, yüzde, minimum, maksimum) yanı sıra nicel verilerin normal dağılıma uygunlukları Shapiro-Wilk testi ve grafiksel analizler ile test edilmiştir. Normal dağılım göstermeyen nicelik yönünden sabit olmayan verileri gruplar arası kıyaslamada Mann Whitney U test kullanıldı. Normal dağılım göstermeyen parametrelerin nicelik yönünden ameliyat öncesi ve ameliyat sonrası ölçümlerinin değerlendirilmesinde Wilcoxon Signed Ranks test tercih edildi. Nicel parametrelerin analizi için Spearman korelasyon işlemlendi. p<0.05 olması istatistiki verilerde anlamlılık olarak değerlendirildi.

\section{Bulgular}

Yaşları 18-53 arasında değişen hastaların ortalaması rakamsal olarak 31.72 77.07 yıldır.

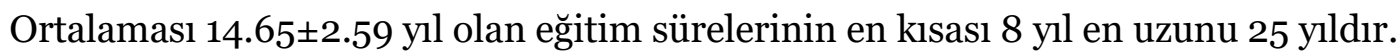

Çalışmaya dahil edilen hastaların \%13.1’i (n=13) kadın, \%86.9’u (n=86) erkek olarak tespit edilmiştir.

Değerlendirdiğimiz hastaların \%64.6'sı (n=64) bekar, \%35.4’ü (n=35) evlidir.

Olguların \%67.7'sinin (n=67) çocuğu yokken, \%32.3’ünün $(n=32)$ çocuğu bulunmaktadır. Olguların \%18.2'si $(\mathrm{n}=18)$ daha önce psikiyatrik tedavi almışken, \%4’ünün ( $n=4)$ devam eden psikiyatrik tedavileri olduğu saptanmıştı (Tablo 1).

Tablo 1. Tanımlayıcı özelliklerin dağılımı

\begin{tabular}{|l|l|l|l|}
\hline \multicolumn{2}{|l|}{} & Min-Mak & Ort \pm ss \\
\hline Yaş (yıl) & $18-53$ & $31.72 \pm 7.07$ \\
\hline Eŭitim süresi (yıl) & $8-25$ & $14.65 \pm 2.59$ \\
\hline & & $\mathbf{n}$ & $\%$ \\
\hline Cinsiyet & Kadın & 13 & 13.1 \\
\cline { 2 - 4 } & Erkek & 86 & 86.9 \\
\hline
\end{tabular}




\begin{tabular}{|l|l|l|l|}
\hline Medeni durum & Bekar & 64 & 64.6 \\
\cline { 2 - 4 } & Evli & 35 & 35.4 \\
\hline Çocuk varı̆ğı & Yok & 67 & 67.7 \\
\cline { 2 - 4 } & Var & 32 & 32.3 \\
\hline \multirow{2}{*}{ Daha önce psikiyatrik tedavi } & Yok & 81 & 81.8 \\
\cline { 2 - 4 } & Var & 18 & 18.2 \\
\hline Devam eden psikiyatrik tedavi & Yok & 95 & 96 \\
\cline { 2 - 4 } & Var & 4 & 4 \\
\hline
\end{tabular}

Vakaların ameliyat öncesine göre ameliyat sonrası RBSÖ skorlarında tespit edilen artıŞ istatistiksel değerlendirmede manalı bulunmuştur ( $\mathrm{p}<0.001)$. Bu da ameliyatın RBSÖ ölçeğine dayanarak olumluluk göstergesi olarak kabul edilebilir.

Çalışmaya dahil edilen hastaların ameliyat öncesine göre ameliyat sonrası SGKÖ puanlarında gözlenen düşüş istatistiki anlamda olumlu olarak tespit edilmiştir (p<0.001). Bu da ameliyatın SGKÖ ölçeğine dayanarak olumluluk göstergesi olarak kabul edilebilir (Tablo 2).

Tablo 2. Ölçek puanlarının değerlendirilmesi

\begin{tabular}{|l|l|l|l|l|l|}
\hline \multicolumn{2}{|l|}{} & $\begin{array}{l}\text { Ameliyat } \\
\text { oncesi }\end{array}$ & $\begin{array}{l}\text { Ameliyat } \\
\text { sonrasi }\end{array}$ & Fark & p \\
\hline \multirow{2}{*}{ RBSÖ } & Medyan $\left(Q_{1}, Q_{3}\right)$ & $24(20,27)$ & $29(26,30)$ & $3(0,8)$ & $<0.001^{* *}$ \\
\cline { 2 - 5 } & Ort $\pm S s$ & $23.88 \pm 4.56$ & $27.69 \pm 2.82$ & $3.81 \pm 5.28$ & \\
\cline { 1 - 5 } SGKÖ & Medyan $\left(Q_{1}, Q_{3}\right)$ & $30(24,41)$ & $24(18,30)$ & $-7(-16,-1)$ & \multirow{2}{*}{$<0.001^{* *}$} \\
\cline { 2 - 5 } & Ort $\pm S S$ & $34.00 \pm 13.45$ & $24.98 \pm 7.91$ & $-9.02 \pm 14.52$ & \\
\cline { 1 - 5 } ROE & Medyan $\left(Q_{1}, Q_{3}\right)$ & $18(11,21)$ & $24(23,24)$ & $6(2,11)$ & \multirow{2}{*}{$<0.001^{* * *}$} \\
\cline { 2 - 5 } & Ort $\pm S s$ & $16.26 \pm 5.54$ & $23.47 \pm 3.13$ & $7.21 \pm 6.29$ & \\
\hline
\end{tabular}

Wilcoxon Signed Ranks Test ${ }^{* *} \mathrm{p}<0.01$ 
Olgular; sosyodemografik açıdan RBSÖ değişimine göre tek tek ele alındığında;

Olguların yaşları ile ameliyat öncesi, ameliyat sonrası RBSÖ puanları ve ameliyat öncesine göre ameliyat sonrası RBSÖ puanlarında tespit edilen farklılık istatistiksel anlamda değerli kabul edilmemiştir ( $\mathrm{p}>0.05$ ) (Tablo 3).

Çalışmaya dahil edilen hastaların eğitim süreleri ile ameliyat öncesi, ameliyat sonrası RBSÖ skorlamaları istatistiki anlamda değerlendirildiğinde anlamlı kabul edilmemiştir (p>0.05) (Tablo 3).

İstatistiksel değerlendirilen eğitim süreleri ile ameliyat öncesine göre ameliyat sonrası RBSÖ skorlamalarında negatif yönde 0.217 değerinde değişimin anlamlılık ifade ettiği tespit edilmiştir (r:-0.217, p: 0.031). Yani eğitim süresi arttıkça ameliyat ile gerçekleşen RBSÖ puanındaki değişim azalmıştır. Bunu düşük eğitim süresi olan hastalarda ameliyatın benlik saygısına katkısının daha fazla olabileceği şeklinde yorumlamamız mümkündür (Tablo 3).

Olguların cinsiyetlerine göre ameliyat öncesi, ameliyat sonrası değişen RBSÖ skorları istatistiksel değerlendirmede anlamlılık arz etmemiştir ( $p>0.05$ ) (Tablo 3).

Erkek olguların ameliyat öncesine kıyasla ameliyat sonrası RBSÖ puanlarında gözlenen değişimin kadın olgularda gözlenen değişimden istatistiki anlamda fazla olduğu tespit edilmiştir (p: 0.029). Bunu ameliyatın benlik saygısına erkek hastalarda kadın hastalara oranla daha fazla katkısı olduğu şeklinde yorumlayabiliriz (Tablo 3).

Olguların medeni durumlarına göre ameliyat öncesi, ameliyat sonrası RBSÖ puanları ve ameliyat öncesine göre ameliyat sonrası RBSÖ puanlarında gözlenen değişim açısından istatistik anlamında değişim tespit edilmemiştir ( $\mathrm{p}>0.05$ ) (Tablo 3).

Çalışmaya dahil edilen hastaların ebeveyn olup olmamalarına göre ameliyat öncesi, ameliyat sonrası RBSÖ puanları ve ameliyat öncesine göre ameliyat sonrası RBSÖ puanlarında gözlenen değişim bakımından istatistiksel olarak anlamlı fark saptanmamıştır ( $\mathrm{p}>0.05$ ) (Tablo 3).

Olguların daha önce psikiyatrik tedavi alma durumlarına göre ameliyat sonrası değişen RBSÖ skorları açısından istatistiki anlamlılık tespit edilmemiştir ( $\mathrm{p}>0.05)$. 
Daha önce psikiyatrik tedavi almış olan olguların ameliyat öncesi RBSÖ puanlarının daha önce psikiyatrik tedavi almamış olan olguların puanlarından sayımlama neticesi ile küçük veya düşük olduğu tespit edilmiştir (p<o.oo1) (Tablo 3).

Daha önce psikiyatrik tedavi almış olan olguların ameliyat öncesine göre ameliyat sonrası RBSÖ puanlarında gözlenen değişimin daha önce psikiyatrik tedavi almamış olan olgularda gözlenen değişimden sayımlama neticesinde büyük olduğu görülmüştür (p: o.017) (Tablo 3).

Olguların devam eden psikiyatrik tedavisi olma durumlarına göre ameliyat sonrası RBSÖ puanları ve ameliyat öncesine göre ameliyat sonrası RBSÖ puanlarında gözlenen değişim bakımından istatistiksel olarak anlamlı fark saptanmamıştır ( $\mathrm{p}>0.05$ ) (Tablo 3).

Devam eden psikiyatrik tedavisi olan olguların ameliyat öncesi RBSÖ puanlarının devam eden psikiyatrik tedavisi olmayan olguların puanlarından istatistiksel olarak anlamlı düzeyde küçük/düşük olduğu saptanmıştır (p: o.o37) (Tablo 3).

Tablo 3. Tanımlayıcı özelliklere göre RBSÖ puanlarının karşılaştırılması

\begin{tabular}{|c|c|c|c|c|c|c|c|}
\hline & \multicolumn{6}{|l|}{ RBSÖ } \\
\hline & & \multicolumn{2}{|c|}{ Ameliyat öncesi } & \multicolumn{2}{|c|}{ Ameliyat sonrası } & \multicolumn{2}{|l|}{ Fark } \\
\hline & & ${ }^{\mathbf{a}} \mathbf{r}$ & $\mathbf{p}$ & $\mathbf{a}_{\mathbf{r}}$ & $\mathbf{p}$ & ${ }^{\mathbf{a}} \mathbf{r}$ & $\mathbf{p}$ \\
\hline \multicolumn{2}{|l|}{ Yaş (yıl) } & 0.061 & 0.549 & -0.015 & 0.881 & -0.074 & 0.467 \\
\hline \multirow{2}{*}{\multicolumn{2}{|c|}{ Ĕ̆itim süresi (yıl) }} & 0.167 & 0.098 & -0.163 & 0.106 & -0.217 & $0.031^{*}$ \\
\hline & & $\begin{array}{l}\text { Medyan }\left(Q_{1},\right. \\
\left.Q_{3}\right)\end{array}$ & ${ }^{\mathbf{b}} \mathbf{p}$ & $\begin{array}{l}\text { Medyan } \\
\left(Q_{1}, Q_{3}\right)\end{array}$ & ${ }^{\mathbf{b}} \mathbf{p}$ & $\begin{array}{l}\text { Medyan } \\
\left(Q_{1}, Q_{3}\right)\end{array}$ & ${ }^{\mathbf{b}} \mathbf{p}$ \\
\hline \multirow[t]{2}{*}{ Cinsiyet } & Kadın & $26(21,28)$ & \multirow[t]{2}{*}{0.344} & $27(24,30)$ & \multirow[t]{2}{*}{0.097} & $1(-2,4)$ & \multirow[t]{2}{*}{$0.029^{*}$} \\
\hline & Erkek & $24(20,27)$ & & $29(27,30)$ & & $3 \cdot 5(1,8)$ & \\
\hline $\begin{array}{l}\text { Medeni } \\
\text { durum }\end{array}$ & Bekar & $25(21,27.5)$ & 0.638 & $\begin{array}{l}28.5(25.5 \\
30)\end{array}$ & 0.571 & $3(0,7 \cdot 5)$ & 0.504 \\
\hline
\end{tabular}




\begin{tabular}{|c|c|c|c|c|c|c|c|}
\hline & Evli & $24(20,27)$ & & $29(27,30)$ & & $3(1,8)$ & \\
\hline \multirow[t]{2}{*}{ Çocuk varlığı } & Yok & $26(21,28)$ & \multirow[t]{2}{*}{0.085} & $29(27,30)$ & \multirow[t]{2}{*}{0.972} & $3(0,7)$ & \multirow[t]{2}{*}{0.213} \\
\hline & Var & $\begin{array}{l}22.5(19.5 \\
26.5)\end{array}$ & & $29(26,30)$ & & $4.5(1,8.5)$ & \\
\hline \multirow{2}{*}{$\begin{array}{l}\text { Daha önce } \\
\text { psikiyatrik } \\
\text { tedavi }\end{array}$} & Yok & $26(21,28)$ & \multirow[t]{2}{*}{$<0.001^{* *}$} & $29(27,30)$ & \multirow[t]{2}{*}{0.654} & $3(0,7)$ & \multirow[t]{2}{*}{$0.017^{*}$} \\
\hline & Var & $20(19,23)$ & & $29(24,30)$ & & $9(1,11)$ & \\
\hline \multirow{2}{*}{$\begin{array}{l}\text { Devam eden } \\
\text { psikiyatrik } \\
\text { tedavi }\end{array}$} & Yok & $25(21,28)$ & \multirow[t]{2}{*}{$0.037^{*}$} & $29(26,30)$ & \multirow[t]{2}{*}{0.700} & $3(0,8)$ & \multirow[t]{2}{*}{0.181} \\
\hline & Var & $19(17.5,22.5)$ & & $\begin{array}{l}28.5(24.5, \\
29.5)\end{array}$ & & $10.5(3,11)$ & \\
\hline
\end{tabular}

ar: Spearman korelasyon katsayısı

b Mann-Whitney U test

${ }^{*} \mathrm{p}<0.05 \quad{ }^{* *} \mathrm{p}<0.01$

$\mathrm{Q}_{1}$ : Birinci çeyreklik, $\mathrm{Q}_{3}$ : Üçüncü çeyreklik

Olguların yaşları ile ameliyat öncesi SGKÖ puanları arasında negatif yönde 0.268 düzeyinde istatistiksel olarak anlamlı ilişki olduğu saptanmıştır (r:-0.268, p: 0.007). Yani operasyon öncesi düşük yaştaki bireylerin yüksek yaştaki bireylere göre daha yüksek SGKÖ puanlarına sahip olduğu görülmüş olup bu da düşük yaş bireylerin yüksek yaş bireylere göre daha olumsuz sosyal görünüş kaygı ölçeğine sahip olduğu şeklinde yorumlanabilir (Tablo 4).

Olguların yaşları ile ameliyat sonrası SGKÖ puanları arasında istatistiksel olarak anlamlı ilişki saptanmamıştır ( $\mathrm{p}>0.05$ ) (Tablo 4).

Olguların yaşları ile ameliyat öncesine göre ameliyat sonrası SGKÖ puanlarında gözlenen değişim arasında pozitif yönde 0.220 düzeyinde istatistiksel olarak anlamlı ilişki olduğu saptanmıştır (r: 0.220, p:0.028) (Tablo 4).

Olguların eğitim süreleri ile ameliyat öncesi, ameliyat sonrası SGKÖ puanları ve ameliyat öncesine göre ameliyat sonrası SGKÖ puanlarında gözlenen değişim arasında istatistiksel olarak anlamlı ilişki saptanmamıştır ( $\mathrm{p}>0.05$ ) (Tablo 4). 
Olguların cinsiyetlerine göre ameliyat öncesi, ameliyat sonrası SGKÖ puanları ve ameliyat öncesine göre ameliyat sonrası SGKÖ puanlarında gözlenen değişim bakımından istatistiksel olarak anlamlı fark saptanmamıştır ( $\mathrm{p}>0.05$ ) (Tablo 4).

Olguların medeni durumlarına göre ameliyat sonrası SGKÖ puanları ve ameliyat öncesine göre ameliyat sonrası SGKÖ puanlarında gözlenen değişim bakımından istatistiksel olarak anlamlı fark saptanmamıştır ( $\mathrm{p}>0.05$ ) (Tablo 4).

Evli olguların ameliyat öncesi SGKÖ puanlarının bekar olguların puanlarından istatistiksel olarak anlamlı düzeyde küçük/düşük olduğu saptanmıştır (p: 0.003) (Tablo 4).

Olguların çocuk varlığına göre ameliyat öncesi, ameliyat sonrası SGKÖ puanları ve ameliyat öncesine göre ameliyat sonrası SGKÖ puanlarında gözlenen değişim bakımından istatistiksel olarak anlamlı fark saptanmamıştır ( $\mathrm{p}>0.05$ ) (Tablo 4).

Olguların daha önce psikiyatrik tedavi alma durumlarına göre ameliyat öncesi, ameliyat sonrası SGKÖ puanları ve ameliyat öncesine göre ameliyat sonrası SGKÖ puanlarında gözlenen değişim bakımından istatistiksel olarak anlamlı fark saptanmamıştır (p>0.05) (Tablo 4).

Olguların devam eden psikiyatrik tedavisi olma durumlarına göre ameliyat öncesi, ameliyat sonrası SGKÖ puanları ve ameliyat öncesine göre ameliyat sonrası SGKÖ puanlarında gözlenen değişim bakımından istatistiksel olarak anlamlı fark saptanmamıştır ( $\mathrm{p}>0.05$ ) (Tablo 4).

Tablo 4. Tanımlayıcı özelliklere göre SGKÖ puanlarının karşılaştırılması

\begin{tabular}{|c|c|c|c|c|c|c|}
\hline & \multicolumn{6}{|c|}{ SGKÖ } \\
\hline & \multicolumn{2}{|c|}{ Ameliyat öncesi } & \multicolumn{2}{|c|}{ Ameliyat sonrası } & \multicolumn{2}{|l|}{ Fark } \\
\hline & ${ }^{a} \mathbf{r}$ & $\mathbf{p}$ & ${ }^{a} \mathbf{r}$ & $\mathbf{p}$ & ${ }^{a} \mathbf{r}$ & $\mathbf{P}$ \\
\hline Yaş (yıl) & -0.268 & $0.007^{* *}$ & -0.022 & 0.826 & 0.220 & $0.028^{*}$ \\
\hline \multirow[t]{2}{*}{ Ĕ̆itim süresi (yıl) } & -0.087 & 0.392 & 0.152 & 0.132 & 0.165 & 0.102 \\
\hline & $\begin{array}{l}\text { Medyan }\left(Q_{1},\right. \\
\left.Q_{3}\right)\end{array}$ & ${ }^{\mathbf{b}} \mathbf{p}$ & $\begin{array}{l}\text { Medyan } \\
\left(Q_{1}, Q_{3}\right)\end{array}$ & ${ }^{\mathbf{b}} \mathbf{p}$ & $\begin{array}{l}\text { Medyan } \\
\left(Q_{1}, Q_{3}\right)\end{array}$ & ${ }^{\mathbf{b}} \mathbf{p}$ \\
\hline
\end{tabular}




\begin{tabular}{|c|c|c|c|c|c|c|c|}
\hline \multirow[t]{2}{*}{ Cinsiyet } & Kadın & $28(24,41)$ & \multirow[t]{2}{*}{0.656} & $24(19,30)$ & \multirow[t]{2}{*}{0.905} & $-5(-12,-3)$ & \multirow[t]{2}{*}{0.752} \\
\hline & Erkek & $30(24,41)$ & & $23.5(18,30)$ & & $-7 \cdot 5(-16,-1)$ & \\
\hline \multirow[t]{2}{*}{ Medeni durum } & Bekar & $32(25.5,44)$ & \multirow[t]{2}{*}{$0.003^{* *}$} & $\begin{array}{l}24 \\
31.5)\end{array}$ & \multirow[t]{2}{*}{0.294} & $-9(-16.5,-3)$ & \multirow[t]{2}{*}{0.075} \\
\hline & Evli & $25(22,36)$ & & $23(18,29)$ & & $-5(-13,0)$ & \\
\hline \multirow[t]{2}{*}{ Çocuk varlı̆̆ } & Yok & $31(24,43)$ & \multirow[t]{2}{*}{0.330} & $24(18,32)$ & \multirow[t]{2}{*}{0.592} & $-8(-16,-2)$ & \multirow[t]{2}{*}{0.739} \\
\hline & Var & $27(24,40)$ & & $23.5(19,28)$ & & $\begin{array}{l}-7 \quad(-15 \cdot 5, \quad- \\
0.5)\end{array}$ & \\
\hline \multirow{2}{*}{$\begin{array}{l}\text { Daha önce } \\
\text { psikiyatrik } \\
\text { tedavi }\end{array}$} & Yok & $29(24,39)$ & \multirow[t]{2}{*}{0.193} & $23(18,31)$ & \multirow[t]{2}{*}{0.902} & $-6(-14,-1)$ & \multirow[t]{2}{*}{0.063} \\
\hline & Var & $38(25,49)$ & & $24.5(19,30)$ & & $-14.5(-24,-5)$ & \\
\hline \multirow{2}{*}{$\begin{array}{l}\text { Devam eden } \\
\text { psikiyatrik } \\
\text { tedavi }\end{array}$} & Yok & $30(24,41)$ & \multirow[t]{2}{*}{0.884} & $23(18,30)$ & \multirow[t]{2}{*}{0.444} & $-7(-16,-1)$ & \multirow[t]{2}{*}{0.791} \\
\hline & Var & $34.5(22,49)$ & & $29.5(23,32)$ & & $-11(-17,1)$ & \\
\hline
\end{tabular}

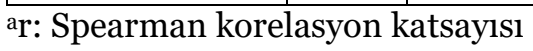

${ }^{\mathrm{b}}$ Mann-Whitney U test

${ }^{*} \mathrm{p}<0.05 \quad{ }^{* *} \mathrm{p}<0.01$

$\mathrm{Q}_{1}$ : Birinci çeyreklik, $\mathrm{Q}_{3}$ : Üçüncü çeyrekli

\section{Tartışma}

Kozmetik cerrahi yaptıranların görünüşünü, tatminkarlığını ve özgüvenini arttırdıkça, çok sayıda psikolojik ve sosyal faktörler de değerlendirmeye alınmaya başlandı ${ }^{6,9}$. Mevcut çalışma, sosyodemografik ve psikolojik etmenler eşliğinde estetik burun cerrahisi geçiren hastaların memnuniyetlerini değerlendirmeyi amaçlamaktadır.

Estetik burun cerrahisi geçiren 99 hasta değerlendirilmiş, sosyodemografik veriler ve kişisel faktörler anket yöntemi ile sorgulanmıştır. Mevcut çalışmanın demografik verileri önceki çalışmaların aksine erkek yoğunluğunu göstermektedir ${ }^{17-19}$.

Biz çalışmamızda olguların yaşları ile ameliyat öncesi, ameliyat sonrası RBSÖ puanları ve ameliyat öncesine göre ameliyat sonrası RBSÖ puanlarında gözlenen değişim arasında istatistiksel olarak anlamlı ilişki saptanmamıştır ( $\mathrm{p}>0.05)$. Bu durumda yaş faktörü göz 
önüne alınarak estetik burun operasyonlarının benlik saygısında değişim yapmayacağı kanaatine varabiliriz.

Olguların yaşları ile ameliyat öncesine göre ameliyat sonrası SGKÖ puanlarında gözlenen değişim arasında pozitif yönde 0.220 düzeyinde istatistiksel olarak anlamlı ilişki olduğu saptanmıştır (r: 0.220, p: 0.028). Bunu yaş arttıkça SGKÖ ölçeğinde artış ve düşük yaştaki bireylerde daha yaşlı bireylere kıyasla, ameliyatla sosyal görünüş kaygı ölçeğinde daha fazla olumlu anlamda değişim olarak yorumlayabiliriz.

Cinsiyetin estetik burun operasyonlarında benlik saygısında veya sosyal görünüş kaygısında ameliyat öncesi ve sonrası anlamlı istatistiksel değişim yapmadığını tespit ettik. Ferraro ve arkadaşlarının²0 çalışmasında ortalama mükemmelliyetçilik skorları erkeklerde daha düşükken bizim çalışmamızda da erkek olguların ameliyat öncesine göre ameliyat sonrası RBSÖ puanlarında gözlenen değişimin kadın olgularda gözlenen değişimden istatistiksel olarak anlamlı düzeyde büyük olduğu saptanmıştır (p:o.o29). Bunu estetik burun operasyonlarının benlik saygısındaki olumlu yönde etkisinin kadınlara göre erkeklerde daha belirgin olduğu şeklinde yorumlayabiliriz.

Olguların eğitim süreleri ile ameliyat öncesine göre ameliyat sonrası RBSÖ puanlarında gözlenen değişim arasında negatif yönde 0.217 düzeyinde istatistiksel olarak anlamlı ilişki olduğu saptanmıştır (r:-0.217, p: o.031). Bu bilgi ile eğitim süresi arttıkça estetik amaçlı burun operasyonu ile muhtemel benlik saygısını arttırma etkisinin azaldığı sonucuna varabiliriz.

Evli olma durumunda bizim çalışmamızda da tıpkı Asadi ve arkadaşlarının çalışmasında olduğu gibi evli olanlar bekar olanlardan daha az yoğunluktaydı ${ }^{21}$. Çalışmamızda olguların \%64.6' sı (n=64) bekar, \%35.4’ü (n=35) evli idi.

Bizim çalışmamızda olguların eğitim süreleri 8 ile 25 yıl arasında değişmekte olup ortalama 14.65 \pm 2.59 yıldır.Önceki çalışmalarda eğitim süresinin fazlalığı ile rinoplasti isteği arasında bir korelasyon görülmüştür ${ }^{17,18,21}$. Olguların eğitim süreleri ile ameliyat öncesine göre ameliyat sonrası RBSÖ puanlarında gözlenen değişim arasında negatif yönde 0.217 düzeyinde istatistiksel olarak anlamlı ilişki olduğu saptanmıştır (r:-0.217, p: o.o31). Eğitim süresi arttıkça benlik saygısı ölçeğine istinaden memnuniyet azalmış gibi yorumlayabiliriz. 
Bazı çalışmalar akraba, arkadaş, tanıdık ve eşlerin de estetik cerrahiye yönelten motivasyonlardan olduğunu söylese de bizim çalışmamızda olguların \% 64.6'sı (n=64) bekar, \%35.4'ü (n=35) evlidir²2. Yine bizim çalışmamızda olguların \% 67.7'sinin (n=67) çocuğu yokken, \%32.3'ünün $(n=32)$ çocuğu bulunmaktadır. Olguların medeni durumlarına göre ameliyat öncesi, ameliyat sonrası RBSÖ puanları ve ameliyat öncesine göre ameliyat sonrası RBSÖ puanlarında gözlenen değişim bakımından istatistiksel olarak anlamlı fark saptanmamıştır ( $\mathrm{p}>0.05)$.

Olguların çocuk varlığına göre ameliyat öncesi, ameliyat sonrası RBSÖ puanları ve ameliyat öncesine göre ameliyat sonrası RBSÖ puanlarında gözlenen değişim bakımından istatistiksel olarak anlamlı fark saptanmamıştır ( $\mathrm{p}>0.05)$.

Olguların medeni durumlarına göre ameliyat sonrası SGKÖ puanları ve ameliyat öncesine göre ameliyat sonrası SGKÖ puanlarında gözlenen değişim bakımından istatistiksel olarak anlamlı fark saptanmamıştır ( $\mathrm{p}>0.05)$.

Farklı olarak evli olguların ameliyat öncesi SGKÖ puanlarının bekar olguların puanlarından istatistiksel olarak anlamlı düzeyde küçük/düşük olduğu saptanmıştır (p: o.o03). Bunu evli bireylerin ameliyat öncesi sosyal görünüş kaygısı değerlendirildiğinde bekar olgulara göre daha olumlu düzeyde oldukları şeklinde yorumlamamız mümkündür.

Olguların çocuk varlığına göre ameliyat öncesi, ameliyat sonrası SGKÖ puanları ve ameliyat öncesine göre ameliyat sonrası SGKÖ puanlarında gözlenen değişim bakımından istatistiksel olarak anlamlı fark saptanmamıştır ( $\mathrm{p}>0.05)$.

Olguların daha önce psikiyatrik tedavi almasının estetik burun operasyonları ile anlamlı düzeyde benlik saygısı veya sosyal görünüş kaygısında etkisi olmadığını tespit ettik.

Daha önce psikiyatrik tedavi almış olan olguların ameliyat öncesi RBSÖ puanlarının daha önce psikiyatrik tedavi almamış olan olguların puanlarından istatistiksel olarak anlamlı düzeyde küçük/düşük olduğu saptanmıştır $(\mathrm{p}<0.001)$. Bu bize daha önce psikiyatrik tedavi almış olguların almamış olanlara kıyasla ameliyat öncesi benlik saygısı ölçeklerinin daha olumsuz olduğunu düşündürebilir.

Daha önce psikiyatrik tedavi almış olan olguların ameliyat öncesine göre ameliyat sonrası RBSÖ puanlarında gözlenen değişimin daha önce psikiyatrik tedavi almamış 
olan olgularda gözlenen değişimden istatistiksel olarak anlamlı düzeyde büyük olduğu saptanmıştır (p:0.017). Bu veri, ameliyatın; daha önce psikiyatrik tedavi almış olgularda almamış olanlara göre benlik saygısını olumlu anlamda arttıran etkisi olarak değerlendirebiliriz.

Olguların devam eden psikiyatrik tedavisi olma durumlarına göre ameliyat sonrası RBSÖ puanları ve ameliyat öncesine göre ameliyat sonrası RBSÖ puanlarında gözlenen değişim bakımından istatistiksel olarak anlamlı fark saptanmamıştır ( $\mathrm{p}>0.05$ ).

Devam eden psikiyatrik tedavisi olan olguların ameliyat öncesi RBSÖ puanlarının devam eden psikiyatrik tedavisi olmayan olguların puanlarından istatistiksel olarak anlamlı düzeyde küçük/düşük olduğu saptanmıştır (p:o.o37). Bunu psikiyatrik sorunların benlik saygısını olumsuz anlamda etkilediği şeklinde yorumlamamız mümkündür.

\section{Sonuç}

Çalışmamızda birçok parametre ayrıntılı olarak değerlendirildi ve hastaları ameliyat sonrası başarı anlamında gözlemlerken pek çok faktörün çok yönlü etki edebileceğini gördük.

Çalışmamızda bazı parametrelerin, genel geçer kabul gören bazı hipotezleri destekler tarzda olduğu görülürken, bazı parametlerin ise sanılanın aksine benlik saygısı veya sosyal görünüş kaygısı üzerinde etkili olmadığını gördük.

Benzer çalışmaların fazla sayıda olgu ile yeniden değerlendirilmesi biz burun estetiği cerrahlarını hastaları ve bulundukları koşulları ve özellikleri göz önüne alınarak değerlendirme açısından donanımlı kılacaktır. Hastaların mevcut koşulları ve operasyon sonrası memnuniyeti etkileyebilecek özellikleri, rinoplasti yapan cerrahları hasta seçimi konusunda yönlendirebilecektir. Bu yüzden bu çalışmanın ve bu çalışma ışı̆̆ında yapılacak daha kapsamlı değerlendirmelerin literatüre katkı sağlaması umudundayız.

\section{KAYNAKLAR}

1. Rettinger G. Risks and complications in rhinoplasty. GMS Curr Top

Otorhinolaryngol Head Neck Surg. 2007; 6: 1-14. 
2. Akbari Sari A, Babashahy S, Olyaeimanesh A, Rashidian A. Estimating the frequency and rate of first 50 common types of invasive procedures in Iran healthcare system. Iran J Public Health. 2012;41(10):60-4.

3. Veale D, Neziroglu F. Body Dysmorphic Disorder: A Treatment Manual. John Wiley and Sons; 2010.

4. Darisi T, Thorne S, Iacobelli C. Influences on decision-making for undergoing plastic surgery: a mental models and quantitative assessment. Plast Reconstr Surg. 2005;116(3):907-16. doi: 10.1097/01.prs.0000177691.81162.e5.

5. Pavan C, Vindigni V, Semenzin M, Mazzoleni F, Gardiolo M, Simonato P, et al. Personality, temperament and clinical scales in an Italian Plastic Surgery setting: what about body dysmorphic disorder? Int J Psychiatry Clin Pract. 2006;10(2):916. doi: 10.1080/13651500500487677.

6. Naraghi M, Atari M. Comparison of patterns of psychopathology in aesthetic rhinoplasty patients versus functional rhinoplasty patients. Otolaryngol Head Neck Surg. 2015;152(2):244-9. doi: 10.1177/0194599814560139.

7. Edgerton MT, Jacobson WE, Meyer E. Surgical-psychiatric study of patients seeking plastic (cosmetic) surgery: ninety-eight consecutive patients with minimal deformity. Br J Plast Surg. 1960 Jul;13:136-45. doi: 10.1016/s00071226(60)80029-x. PMID: 13819311.

8. Green SP, Pritchard ME. Predictors of body image dissatisfaction in adult men and women. Soc Behav Pers. 2003;31:215-222. https://doi.org/10.2224/sbp.2004.31.3.215.

9. Kucur C, Kuduban O, Ozturk A, Gozeler MS, Ozbay I, Deveci E, et al. Psychological evaluation of patients seeking rhinoplasty. Eurasian J Med. 2016;48(2):102-6. doi:10.5152/eurasianjmed.2015.103.

10. Sarwer DB, Wadden TA, Pertschuk MJ, Whitaker LA. The psychology of cosmetic surgery: a review and reconceptualization. Clin Psychol Rev. 1998;18(1):1-22. doi:10.1016/s0272-7358(97)00047-0.

11. Sarwer DB, Cash TF, Magee L, et al. Female college students and cosmetic surgery: an investigation of experiences, attitudes, and body image. Plast Reconstr Surg. 2005;115(3):931-8. doi:10.1097/01.prs.0000153204.37065.d3. 
12. Cash TF, Labarge AS. Development of the appearance schemas inventory: a new cognitive body-image assessment. Cognşt Ther Res. 1996;20:37-50. https://doi.org/10.1007/BFo2229242.

13. Abbas OL, Kurkcuoglu A, Aytop CD, Uysal C, Pelin C. Perception of symmetry in aesthetic rhinoplasty patients: anthropometric, demographic, and psychological analysis. Perception. 2017;46(10):1151-1170. doi: 10.1177/0301006617714214.

14. Hilhorst MT. Philosophical pitfalls in cosmetic surgery: a case of rhinoplasty during adolescence. Med Humanit. 2002 Dec;28(2):61-5. doi: 10.1136/mh.28.2.61.

15. Sarwer D, Magee L. Physical Appearance and Society.Lippincott Williams \& Wilkins Publishers; 2006.

16. Marsh HW. Age and gender effects in physical self-concepts for adolescent elite athletes and non athletes: a multicohort-multioccasion design. Sport Exerc Psychol. 1998;20:237-259. https://doi.org/10.1123/jsep.20.3.237.

17. Zojaji R, Arshadi HR, Keshavarz M, Mazloum Farsibaf M, Golzari F, Khorashadizadeh M. Personality characteristics of patients seeking cosmetic rhinoplasty. Aesthetic Plast Surg. 2014;38(6):1090-3. doi: 10.1007/s00266-0140402-7.

18. Furnham A, Levitas J. Factors that motivate people to undergo cosmetic surgery. Can J Plast Surg. 2012;20(4):e47-50.

19. Hashemi SAG, Edalatnoor B, Edalatnoor B, Niksun O. A comparison of body image concern in candidates for rhinoplasty and therapeutic surgery. Electron Physician. 2017;9(9):5363-5368. doi: 10.19082/5363.

20. Ferraro GA, Rossano F, D'Andrea F. Self-perception and self-esteem of patients seeking cosmetic surgery. Aesthetic Plast Surg. 2005;29(3):184-9. doi: 10.1007/s00266-004-0124-3.

21. Asadi M, Salehi M, Sadooghi M, Ebrahimi AA. Self-esteem and attitude toward body appearance before and after cosmetic rhinoplasty. Iran $J$ Psychiatry Clin PSychol. 2013;19:28-33.

22. von Soest T, Kvalem IL, Skolleborg KC, Roald HE. Psychosocial factors predicting the motivation to undergo cosmetic surgery. Plast Reconstr Surg. 2006;117(1):5162; discussion 63-4. doi: 10.1097/o1.prs.0000194902.89912.f1. 